einer ganzheitlichen Naturschutzstrategie / Bearb. von Behrens H., Sacher P., Wegener U. Berlin: Verlag für Wissenschaft und Forschung, 2002. S. 5-47.

25. Knaut A. Zurück zur Natur! Die Wurzeln der Ökobewegung, Suppl. 1 zum Jahrbuch für Naturschutz und Landschaftspflege. Greven: Kilga-Verlag, 1993. 480 S.

26. Schoenichen $W$. Naturschutz - Heimatschutz. Große Naturforscher. B. 16. Stuttgart: Wissenschaftliche Verlaggesellschaft M.B.H., 1954. 311 S.

27. Blab J. Schutzgebiete in Deutschland - Entwicklung mit historischer Perspektive // Natur und Landschaft. 2006. Heft 1. S. 8-11.

28. Barthelmeß A. Landschaft. Lebensraum des Menschen. Probleme von Landschaftsschutz und Landschaftspflege geschichtlich dargestellt und dokumentiert. Freiburg; München: Verlag Karl Alber, 1988. 384 S.

29. Offner H. Die Lüneburger Heide // Jahrbuch Preussischer Kulturbesitz. 1971. Sonderdruck. № IX. S. 3-20.

30. Lerche H.-J. Die Teufelsmauer bei Weddersleben und Warnstedt // 150 Jahre Schutz der Teufelsmauer. Berichte des Landesamtes für Umweltschutz Sachsen-Anhalt / Red. K. George, H.-J. Lerche u. a. Halle: Landesamt für Umweltschutz Sachsen-Anhalt, 2002. S. 6-11.
31. Stempel A., Ohlendorf B. Zur Bedeutung, Pflege und Entwicklung des NSG «Teufelsmauer»// Ibid. S. 16-19.

32. Rudorff $E$. Über das Verhältnis des modernen Lebens zur Natur // Natur und Landschaft. 1990. Heft 3. S. 119-125.

33. Funkel C., George K. Die «Teufelsmauer»-eines der frühesten Schutzobjekte in Deutschland - älter als gedacht // Naturschutz im Land Sachsen-Anhalt. 2002. Heft 2. S. 50-52.

34. Kaiser T., Lütkepohl M., Prüter J. Das Naturschutzgebiet Lüneburger Heide als Beispielgebiet des Werkstattgesprächs «Naturschutzleitbilder»// Schriftenreihe des Deutschen Rates für Landespflege. 1997. Heft 67. S. 71-73.

35. Floericke K. Entwicklung, Stand und Aussichten der Naturschutzparkbewegung // Naturschutzparke in Deutschland und Österreich. Ein Mahnwort an das deutsche und österreichische Volk. Hrsg. vom Verein Naturschutzpark e. V. Sitz Stuttgart. Stuttgart: Frank'sche Verlagshandlung, o. J. S. 7-18. 36. Guenther K. Der Naturschutz. Freiburg i. B.: Verlag Friedrich Ernst Fehlenfeld, 1910. 278 S.

37. Der Verein Naturschutzpark e.V. besteht 80 Jahre. Die Geschichte des Vereins in Stichworten von 1909 bis 1988 // Naturschutz- und Naturparke. Mitteilungen des Vereins Naturschutzpark e.V. und des Verbandes Deutscher Naturparke e.V. 3. Vierteljahr 1989. Heft 134. S. 41-47.

\title{
КРУПНОМАСШТАБНОЕ ЛАНДШАФТНОЕ КАРТОГРАФИРОВАНИЕ (на ПрИмере полупустынного Саратовского Приузенья)
}

\section{Н.В. Пичугина, А.В. Фёдоров ${ }^{1}$}

Саратовский государственный университет, кафедра физической географии и ландшафтной экологии,

${ }^{1}$ кафедра геоморфологии и геоэкологии,

E-mail: geogr@sgu.ru

Статья посвящена вопросам картографирования локальных геосистем полупустынного Саратовского Приузенья, а также возможностям использования картографических произведений для определения ландшафтной структуры и ее изменений вследствие антропогенной нагрузки на территорию. В работе использованы материалы полевых исследований разных лет, топографические и тематические карты, космические снимки, элементы геоинформационных технологий.

Ключевые слова: картографирование, ландшафты, полупустыня, Саратовская область, Заволжье.

\section{Large-Scale Landscape Mapping (Semi-Desert Saratov Priuzenye as an Example)}

\section{N.V. Pichugina, A.V. Fedorov}

The article is devoted to mapping questions of local semi-desert Saratov Priuzenye geosystems and facilities of cartographical works using for landscape structure identification and it's variation as a result of anthropogenic load on the territory. Different ages field research, topographical and thematical maps, space images, geoinformation technology' elements are used in the work.

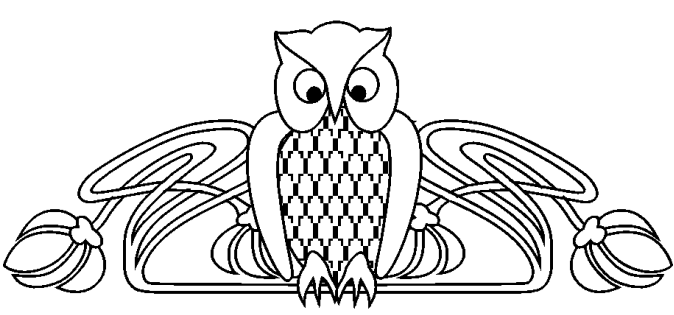

Key words: mapping, landscapes, semi-desert, Saratov Region, Zavolzhye.

Основным назначением ландшафтного картографирования выступает разработка методики составления, оформления и анализа картографических произведений, отображающих природные и природно-антропогенные геосистемы локальной, региональной и планетарной размерностей.

Целью данной статьи является рассмотрение возможностей использования крупномасштабного картографирования геосистем локального уровня для изучения ландшафтной структуры, а также ее трансформации в процессе сельскохозяйственного использования территории.

В качестве объекта исследования была выбрана Приузенская равнина с трехчленными пустынно-степными комплексами (ПСК). Административно она охватывает юго-западную часть Новоузенского района (к югу от широты г. Новоузенска) и Александрово-Гайский район Саратовской области.

Актуальность выбранной темы определяется необходимостью оптимизации структуры землепользования территории.

Исходные материалы и источники. При написании статьи были использованы материа- 
лы полевых исследований 1997, 1998 и 2010 гг., топографические и тематические (почвенные, ландшафтные и др.) карты, космические снимки, научные публикации (монографии, статьи).

Методы исследования: описательный, сравнительный, картографический с использованием геоинформационных технологий и данных дистанционного зондирования Земли. Для определения пространственных характеристик изучаемых объектов (местоположение, абсолютная высота) применялось оборудование системы глобального позиционирования GPS.

История вопроса. Крупномасштабное картографирование пробных участков (10х10, 50х50 и $100 \times 100$ м) для исследования ландшафтной структуры территории Нижнего Заволжья было использовано участниками Нижневолжской экспедиции АН СССР под руководством Б.А. Келлера в 1932 г., а также при полустационарных исследованиях в 1933 г. [1]. На этих картах отображены основные звенья двучленных и трехчленных комплексов. Саратовское Приузенье подобными картографическими работами во время этой экспедиции не было затронуто.

В 1991 г. картографирование фациальной структуры и нивелирная съемка рельефа были выполнены под руководством В.А. Николаева для ключевого участка (30x48 м) на территории Джа- ныбекского стационара (Казахстан) [2]. В 1998 г. аналогичная работа была проведена Н.В. Пичугиной на ключевом участке $(30 \times 50$ м) УзенскоБольшелиманского ландшафта (АлександровоГайский административный район).

Исследуемая территория согласно ландшафтному районированию Саратовского Заволжья [3] входит в состав Приузенского ландшафтного района северной полупустыни Прикаспийской низменности. Здесь представлено четыре зональных ландшафта и два интразональных долинных ландшафта [3, 4]. Между рр. Большой Узень и Малый Узень находятся Межузенские северный и южный ландшафты, а в левобережной части Большого Узеня - Узенско-Дюринский и Узенско-Большелиманский ландшафты. Абсолютные высоты на междуречных пространствах меняются от 38-40 м на севере до 18-20 м на юге.

Основными элементами ландшафтной структуры исследуемой территории являются: аккумулятивные плоские и слабонаклонные равнины с двучленными и трехчленными пустынностепными комплексами (ПСК); урочища падин и лиманов, а также долинные геосистемы. Равнины с трехчленными пустынно-степными комплексами (рис. 1) в структуре зональных ландшафтов занимают $68-83 \%$ от их площади.

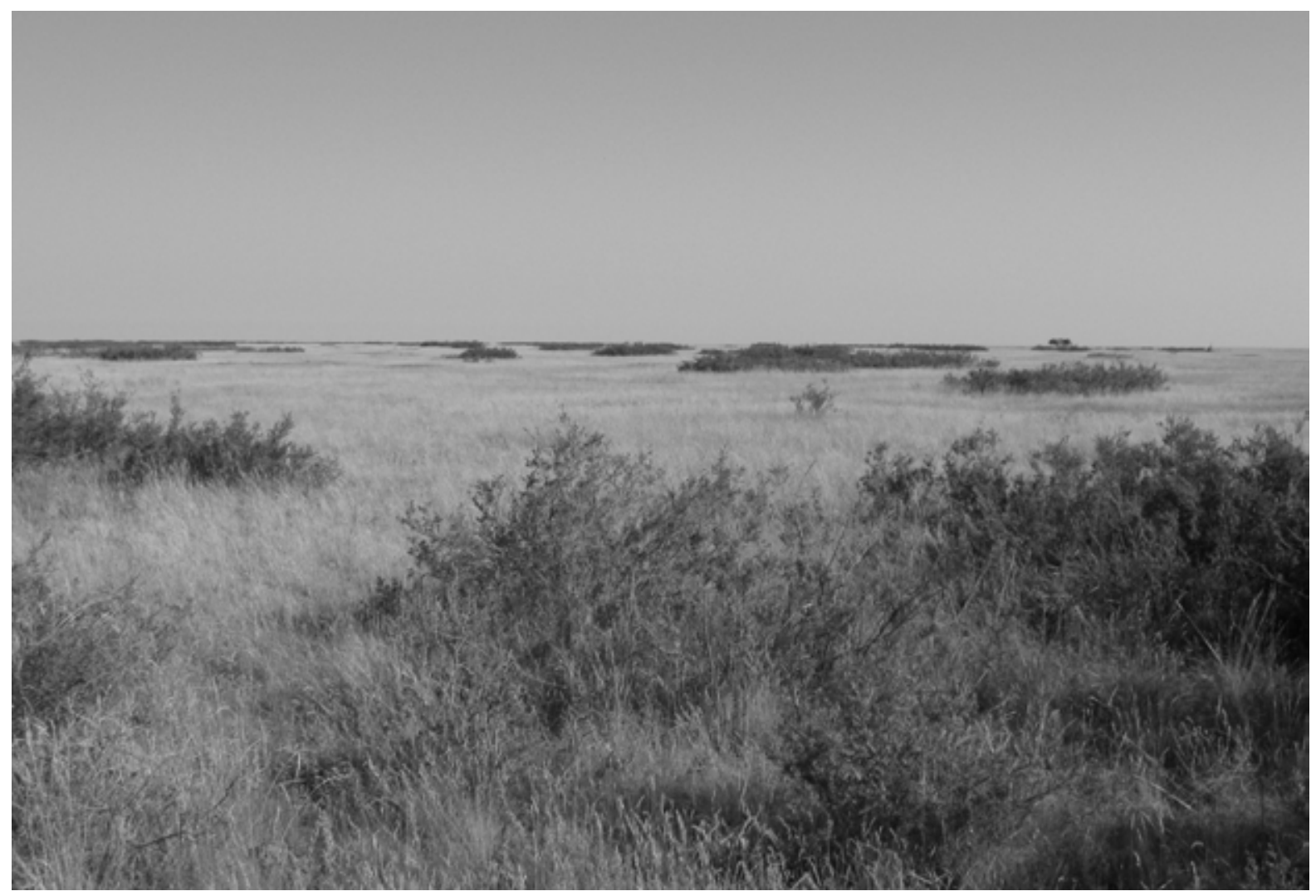

Рис. 1. Трехчленный пустынно-степной комплекс (ПСК) Узенско-Большелиманского ландшафта (фотография Н.В. Пичугиной, 2010 г.) 
Локальный уровень ландшафтных исследований.

На ландшафтных картах $1: 50000$ и $1: 100000$ масштаба, как правило, отображены такие единицы, как ландшафтный район, ландшафт, местности, а также наиболее крупные урочища. Для более детального выявления ландшафтной структуры может быть использовано крупномасштабное картографирование ключевых участков. Оно раскрывает фациальную дифференциацию территории.

Методика работы на ключевом участке.

1. Выбор площадки размером 20x40, 30-50 м и т.п. В ее пределах должно оказаться максимальное число элементов исследуемой территории или тех из них, которые представляют наибольший интерес.

2. Участок съемки разбивается на квадратыполигоны со стороной 1,2 м или более. Угол каждого полигона фиксируется колышком, который затем используется в качестве постоянного пикета.

3. На миллиметровой бумаге в масштабе $1: 100$ наносятся границы участка и полигонов, а также проводится сплошная нумерация основных (постоянных) пикетов. Затем последовательно по полигонам осуществляется нанесение границ локальных геосистем с использованием растительных ассоциаций в качестве индикатора.

4. Параллельно ведется полевой журнал ландшафтной съемки, в котором отражается подробная характеристика выделенных фаций с описанием элемента рельефа и растительного покрова. Каждой из выделенных фаций присваивается свой индивидуальный номер или проводится предварительная группировка, когда однотипные фации обозначают одинаковым порядковым номером.

5. В том случае, если планируется проведение многолетних наблюдений на данном участке, для описания почв закладываются шурфы рядом с исследуемой площадкой под такими же растительными сообществами, что и на ключе. На ключевом участке может быть использован почвенный бур, а также приборы, позволяющие определить $\mathrm{pH}$ и влажность почвы.

6. В том случае, когда требуется проведение более детального анализа приуроченности фаций к определенным местоположениям, используется инструментальная съемка рельефа исследуемого ключевого участка. На миллиметровой бумаге создается второй экземпляр плана участка с разбивкой его на полигоны и указанием пикетов. Затем выбирается место для «станции» (т.е. для установки нивелира) и последовательно по основным пикетам проводится геометрическое нивелирование поверхности ключевого участка. Если внутри полигонов или вдоль их сторон между основными пикетами наблюдается изменение высоты, то в этих точках устанавливаются дополнительные пикеты.
7. В «камеральный» этап ландшафтной съемки входит оформление ландшафтной карты. Для этого целесообразно воспользоваться возможностями геоинформационных технологий. С помощью сканера осуществляется перевод в электронный вид топографической и тематической информации с бумажных основ. После привязки растра в программе Mapinfo осуществляется векторизация (цифрование), т.е. перевод информации из растровой формы в векторный вид, а также ввод атрибутивных данных по каждому из объектов.

8. Завершающим этапом являются обработка и анализ полученных баз данных с использованием инструментов геоинформационного моделирования, например построения цифровой модели местности, оверлейных операций и т.п.

Исследование Узенско-Большелиманского ландшафта.

Крупномасштабное картографирование $(1: 100)$ было проведено на ключевом участке (30x50 м) с трехчленным пустынно-степным комплексом в пределах Узенско-Большелиманского ландшафта (рис. 2). Эта территория в настоящее время является частью памятника природы регионального значения «Ляляевская комплексная полупустыня» [5]. Участок используется под выпас и прогон скота.

Для выявления фациальной приуроченности к высотным уровням было проведено геометрическое нивелирование поверхности ключевого участка (рис. 3). В связи с незначительной площадью исследуемого участка и малой разницей высот за относительный ноль была принята самая низкая точка на участке, которая находится в микрозападине с зарослями спиреи. Максимальная высота находится на сусликовине и составляет 52,4 см. После обработки полученного материала были построены карты рельефа с сечением в 1 см, а также гипсометрических уровней с шагом в $5 \mathrm{~cm}$ (см. рис. 3).

Для наглядности была построена трехмерная цифровая модель рельефа с оверлеем фациальной дифференциации (рис. 4).

Исследование Межузенского южного ландшафта.

Межузенский южный ландшафт находится на юге Александрово-Гайского района в пределах междуречья Большого и Малого Узеней. Для картографирования было выбрано три ключевых площадки (500х500 м) с трехчленным пустынностепным комплексом между хуторами Байгужа, Вишневка и Тюленев. Абсолютные высоты здесь составляют 23-25 м н.у.м. Одна из площадок представлена в статье (рис. 5). Картографирование проводилось по космическим снимкам высокого разрешения, при дешифрировании которых использовались материалы полевых исследований (2010 г.). 

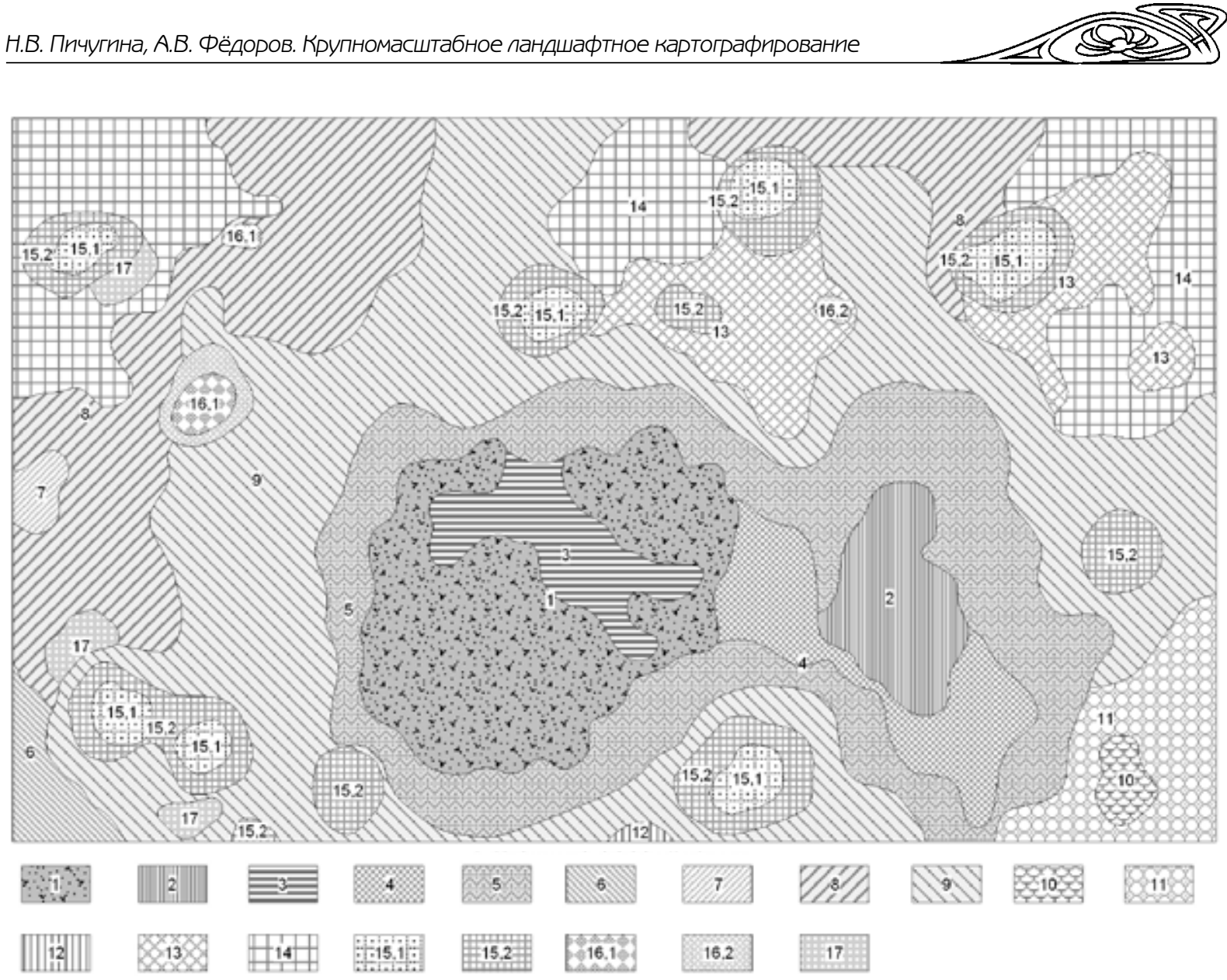

Рис. 2. Узенско-Большелиманский ландшафт: фациальная структура ключевого участка (30х50 м) с трехчленным пустынно-степным комплексом:

степные и лугово-степные фаиии микрозападин:

1 - ковыльно-богаторазнотравно-кострово-узколистномятликовая ассоциация (восьмилепестник, вейник, ковыль Залесского) со спиреей (высота 1-1,7 м), п/п 100\%, на лугово-каштановых тяжелосуглинистых почвах;

2 - осоково-богаторазнотравно-грудницево-ковыльная с участием тонконога, тысячелистника, кермека, гвоздики и с куртинами спиреи (высота 0,2-0,5 м), п/п 95\%, на лугово-каштановых тяжелосуглинистых почвах;

3 - богаторазнотравно-ковыльная ассоциация (ковыль Залесского, вейник, гвоздика, восьмилепестник, коровяк, спаржа, пырей, тырса) с п/п 95\% на луговато-каштановых тяжелосуглинистых почвах;

4 - богаторазнотравно-тонконогово-пырейно-грудницево-ковыльная ассоциация с п/п 90-95\% на луговато-каштановых тяжелосуглинистых почвах;

5 - типчаково-разнотравно-тонконогово-ковылковая ассоциация (грудница, гвоздика, дымнянка, коровяк, кермек, василек, тырса, подмаренник, тысячелистник, полынь) с п/п 80-85\% на луговато-каштановых тяжелосуглинистых почвах; пустынно-степные фачии микросклонов к западинам: 6 - ксерофитно-разнотравно-тонконогово-ромашниковотипчаково-ковылковая ассоциация с участием осочки, мятлика, полынка, п/п 80\%, на светло-каштановых тяжелосуглинистых почвах;

7-ксерофитно-разнотравно-острецово-типчаково-пустынножитняково-ромашниковая ассоциация с п/п 70\% на светлокаштановых тяжелосуглинистых солонцеватых почвах; 8 - прутняково-камфоросмово-ромашниково-мятликовоострецовая ассоциация с участием накипных лишайников и житняка пустынного, п/п 70\%, на светло-каштановых тяжелосуглинистых солонцеватых почвах;
9 - типчаково-прутняково-чернополынная ассоциация с участием мятлика, остреца, п/п 60\%, на светло-каштановых тяжелосуглинистых солонцеватых почвах;

солонциово-пустынно-степные и солонцово-пустынные фации микроповымений:

10 - тонконогово-пустынножитняково-острецово-мятликово-типчаково-полынно-ромашниковая ассоциация с п/п 75\% на солонцах средних и мелких солончаковых и солончаковатых;

11 - острецово-прутняково-мятликово-полынная ассоциация с п/п 60\% на солонцах мелких и средних солончаковых; 12 - ромашниково-полынно-типчаково-мятликовая ассоциация с п/п 50\% на солонцах мелких и средних солончаковых;

13 - мятликово-чернополынно-камфоросмово-прутняковая ассоциация с п/п 50\% на солонцах средних и мелких солончаковых;

14 - прутняково-чернополынная, мятликово-прутняковочернополынная, мятликово-чернополынная ассоциации с п/п 45-55\% на солонцах мелких и корковых солончаковых; фаичи сусликовин:

15.1 - прутняково-камфоросмово-солянковая ассоциация с п/п 5-10\% на свежих карбонатно-соленосных выбросах сусликовин;

15.2 - мятликово-чернополынно-прутняковая ассоциация с п/п 20-45\% на шлейфах сусликовин;

16.1 - острецово-прутняково-ромашниково-чернополынная ассоциация с п/п 45-55\% на зарастающих сусликовинах;

16.2 - острецово-мятликово-полынковая ассоциация с п/п 45-55\% на зарастающих сусликовинах;

17 - ковылково-мятликово-полынно-острецово-тонконогово-ромашниковая ассоциация с п/п 55-70\% на старых просевших заросших сусликовинах 

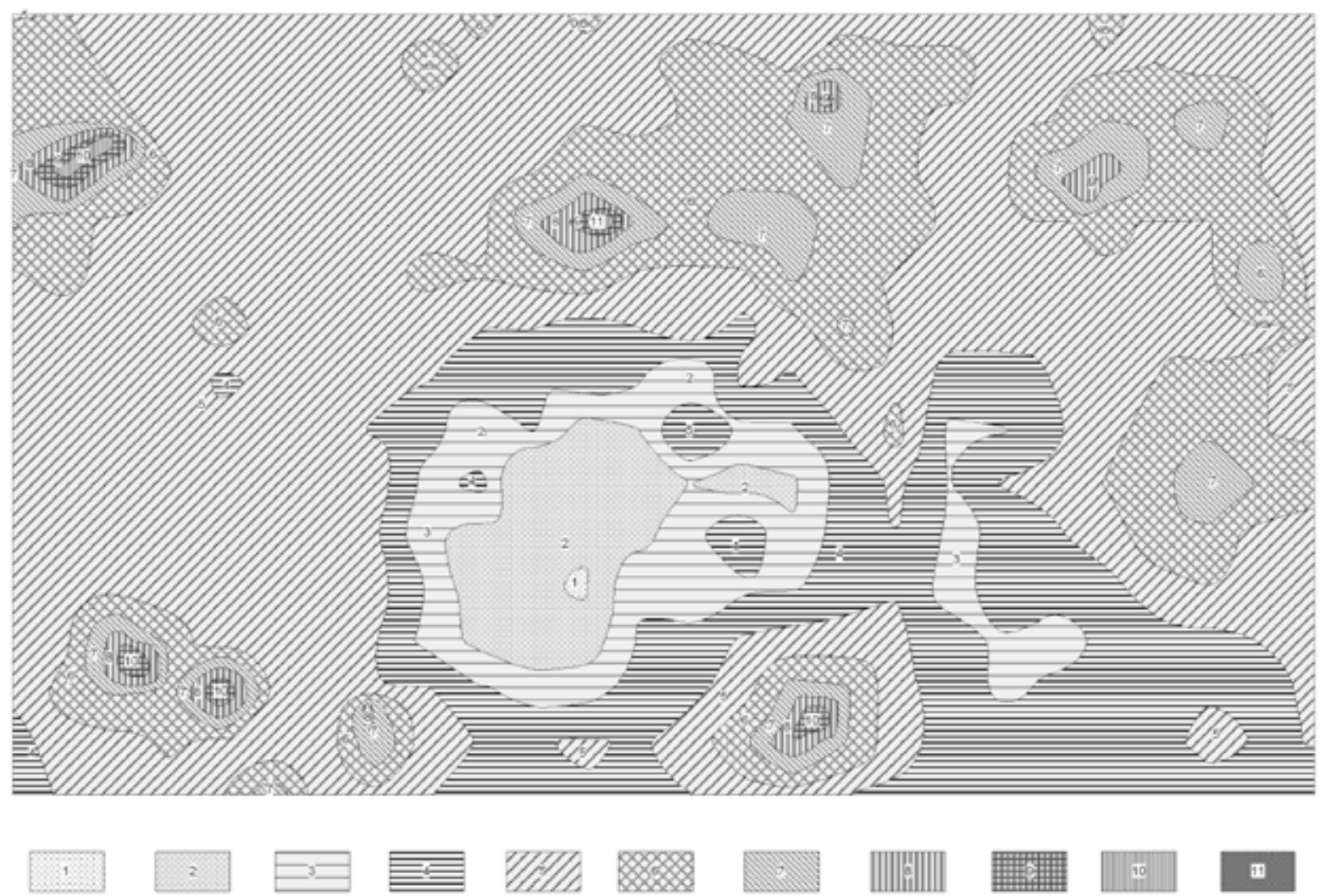

Рис. 3. Узенско-Большелиманский полупустынный ландшафт: гипсометрические уровни (см.) ключевого участка (30х50 м) с трехчленным комплексом: $1-0-5 ; 2-5-10 ; 3-10-15 ; 4-15-20 ; 5-20-25 ; 6-25-30 ; 7-30-35 ; 8-35-40$; $9-40-45 ; 10-45-50 ; 11-50-55$

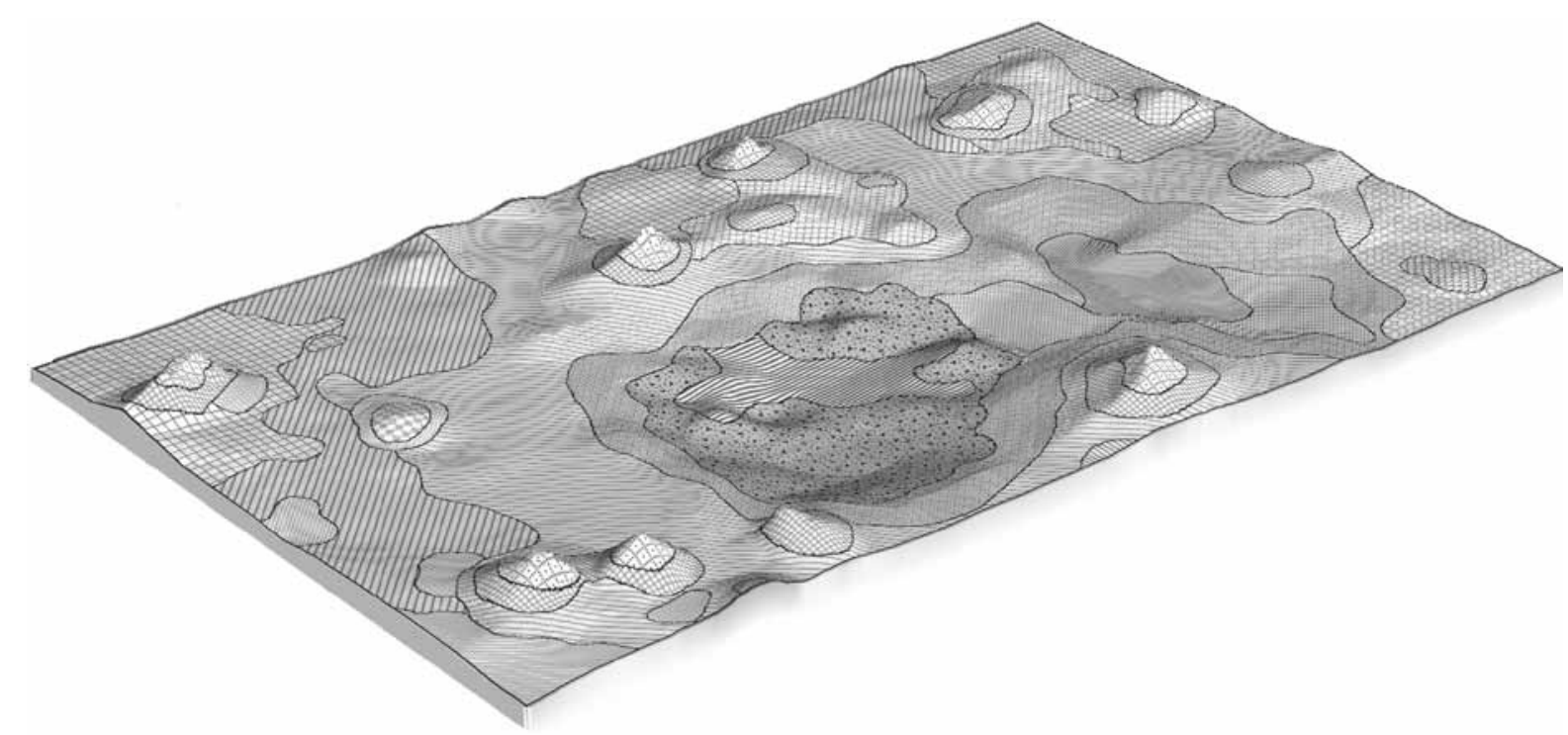

Рис. 4. Узенско-Большелиманский ландшафт: трехмерная модель рельефа с оверлеем фациальной структуры ключевого участка (30х50 м) с трехчленным пустынно-степным комплексом 


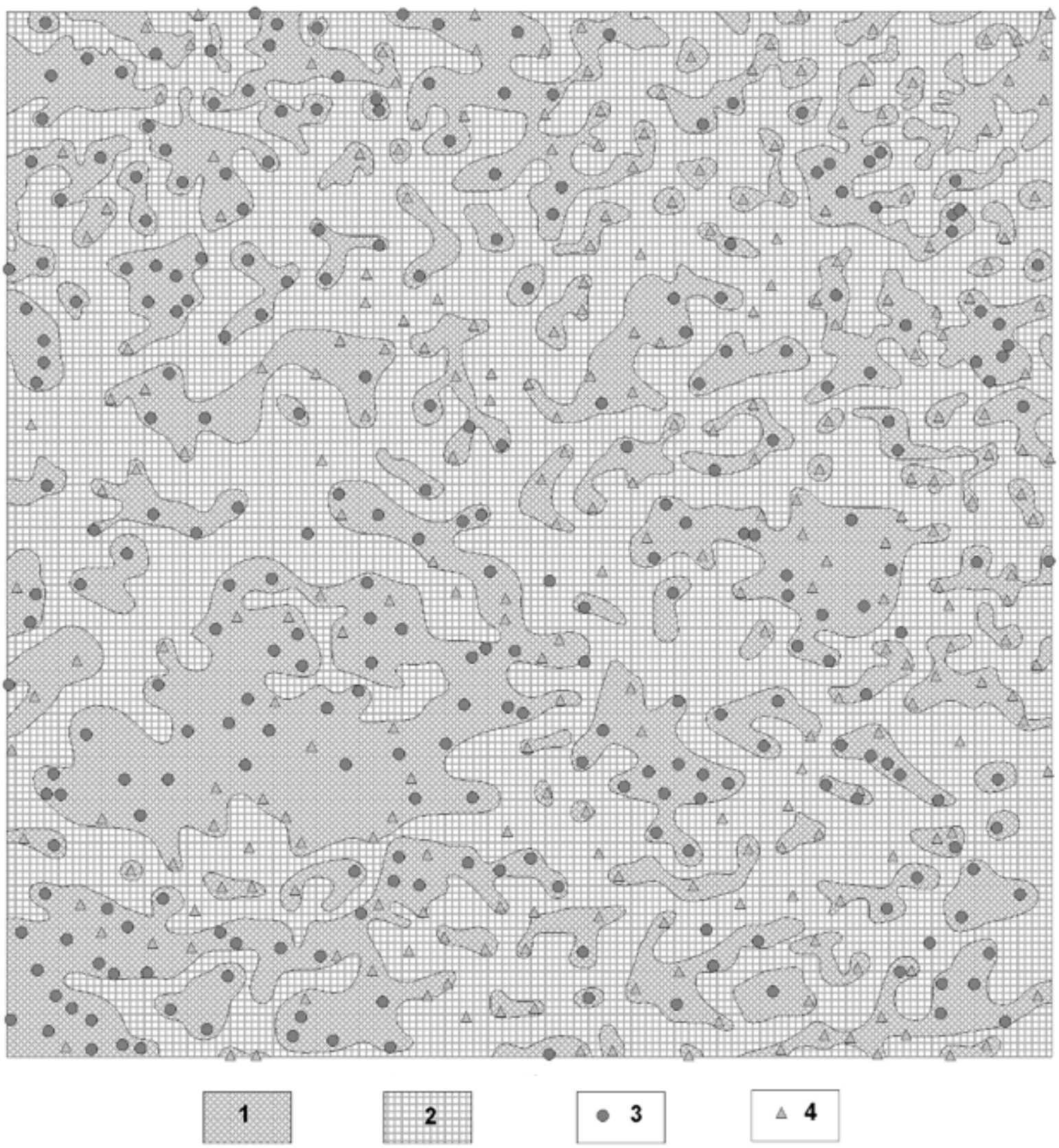

Рис. 5. Пространственная дифференциация основных элементов ключевой площадки (500х500 м) с трехчленным пустынно-степным комплексом на Межузенском южном ландшафте: группы фаций: 1 - пустынно-степные фации микросклонов к западинам; 2 - солонцово-пустынно-степные фации микроповышений с сусликовинами; 3 - лугово-степные фации микрозападин с злаково-разнотравной растительностью и зарослями спиреи; 4 -лугово-степные и степные фации микрозападин с тонконогово-житняково-пырейными сообществами

Для рассматриваемого участка, согласно проведенным расчетам, характерно следующее долевое участие основных элементов трехчленного комплекса. Пустынно-степные фации микросклонов на светло-каштановых почвах занимают около $43 \%$, солонцовопустынно-степные фации микроповышений на солонцах - 41\%, по $8,5 \%$ приходится на микрозападины с зарослями спиреи на лугово- каштановых почвах, а также на микропонижения с тонконогово-житняково-пырейными сообществами на луговато-каштановых почвах. Диаметр западин варьирует от 3-5 до 17-20 м. Солонцово-пустынно-степные фации осложняют сусликовины, наиболее значительные из которых занимают чуть более 1\% (333 шт.) от площади участка. Исследуемый участок используется под прогон скота. 


\section{Выводы}

1. Ландшафтное картографирование ключевых участков размером 30×50, 10х10 м и т.п. позволяет выявлять фациальную дифференциацию территории, а при многолетних наблюдениях дает возможность определять основные направления изменения ландшафтной структуры. В пределах Узенско-Большелиманского ландшафта антропогенная трансформация связана преимущественно с выпасом скота. Пастбищная нагрузка ведет к ухудшению состояния кустарникового элемента в трехчленном комплексе. Высота спиреи составляет 0,5-0,7 м, а до интенсивного выпаса достигала 1,7 м. В угнетенном состоянии находятся представители разнотравья. В растительном покрове начинают преобладать сообщества с доминированием полыни, прежде всего черной. Разрыхление верхнего почвенного горизонта неизбежно создает благоприятные условия для развития ветровой эрозии.

2. Ландшафтное картографирование ключевых площадок размером 500х500 м дает возможность определения основных элементов и их долевого участия в структуре отдельных местностей. Закладка площадок, характеризующихся разным хозяйственным использованием, позволяет прогнозировать возможные пути развития при снижении или увеличении нагрузки.

Исследования, проведенные на ключевых площадках в окрестностях хут. Байгужа, позволили выявить некоторые особенности развития территории. Участок, который до середины 90-х гг. ХХ в. использовался в качестве пашни, в настоящее время представлен залежью. В результате механической обработки земли из структуры трехчленного комплекса выпали такие элементы, как сусликовины, западины с зарослями спиреи. Вместе с тем дешифрирование космических снимков показало, что западины хорошо читаемы. Полевые работы подтвердили, что западины, несмотря на период земледельческого использования, сохранили свою индивидуальность. В настоящее время в них преобладают тонконоговожитняково-пырейные сообщества с очень небольшим участием разнотравья. В отдельных западинах, расположенных ближе к целинным участкам, появляются одиночные кустики спиреи. Если распашка затрагивала лиманные понижения, то в них пырейные сообщества нередко начинали сочетаться с рассеянным или куртинным восстановлением солодки.

Протяженность скотобойных троп на ключевой площадке, представленной в статье (см. рис. 5), составила 13,2 км. Ширина скотобойной тропы достигает 23-25 см, глубина - от 3-5 до 10 см. Около 1,3\% исследуемой площадки занято скотобойными тропами с распыленным верхним горизонтом.

В целом следует отметить, что возможности крупномасштабного ландшафтного картографирования с использованием данных дистанционного зондирования Земли и геоинформационных технологий еще до конца не раскрыты и требуют дальнейших исследований.

\section{Библиографический список}

1. Растительность Каспийской низменности между реками Волгой и Уралом / Под ред. Б.А. Келлера: В 2 т. М.; Л., 1936. Т. 1. 295 с.

2. Николаев В.А., Копьл И.В., Пичугина Н.В. Фациальная структура полупустынного ландшафта в Северном Прикаспии // Вестн. Моск. ун-та. Сер. 5, Геогр. 1995. № 2. C. 74-83.

3. Макаров В.3., Пичугина Н.В., Павлова А.Н. Некоторые аспекты методики составления ландшафтных карт разного масштаба (на примере Саратовского Заволжья) //Поволжский экологический журнал. 2008. № 4. С. 293-303.

4. Пичугина Н.В. Ландшафтная структура полупустынного Саратовского Приузенья // Ландшафтоведение: теория, методы, региональные исследования, практика: Материалы XI Междунар. ландшафтной конф. Москва, 22-25 августа, 2006 г. / Отв. ред. К.Н. Дьяконов. М., 2006. С. 230-232.

5. Пичугина Н.В., Завьялов Е.В. Александрово-Гайские культюки. Леляевская комплексная полупустыня. Лиманы Глубокий, Крутой // Особо охраняемые природные территории Саратовской области: национальный парк, природные микрозаповедники, памятники природы, дендрарий, ботанический сад, особо охраняемые геологические объекты / Науч. ред. В.З. Макаров; Комитет охраны окружающей среды и природопользования Саратовской области. Саратов, 2007. С. 48-54. 